\title{
Knowledge Management and Analysis of Scientific Biotechnology Trends in Venezuela
}

\author{
Maria de Fátima Ebole de Santana', Rosalba Gómez Martínez², Nei Pereira Jr. ${ }^{3}$, \\ Adelaide Maria de Souza Antunes ${ }^{4}$
}

\begin{abstract}
This paper presents a study on knowledge management and analysis of scientific Biotechnology trends in Venezuela, providing an overview of the science profile as well as regional development and its relation to issues of topics covered by Biotechnology based on the analysis of scientific publications for the period of 1995 to 2010 . The survey was accomplished in database ISI/Web of Science using 60 terms selected by experts in Biotechnology and 803 register has been organized. Scientific indicators were produced using data/ text mining tools. It was possible to find a greater number of scientific publications in areas such as Ecology and Health, showing a greater frequency in these terms: DNA, PCR and Biodiversity. Results pointed out The United States of America as the main foreign partner-country of scientific publications followed by Spain and France. It was possible to verify cooperation network with others Latin American countries: Brazil, Colombia and Chile.
\end{abstract}

Keywords: Venezuela; biotechnology; knowledge management; technological networks; scientific capabilities.

\footnotetext{
' Escola de Química Universidade / Federal do Rio de Janeiro (UFRJ).Av.Athos da Silveira Ramos, I49. Centro de Tecnologia. Rio de Janeiro, RJ, Brasil.Zipcode: 2194I-909.Tel: + 55 2I 2562-7560.Email: mfebole@gmail.com

2 Universidad Experimental Francisco de Miranda (UNEFM). Prolongación Av. Manaure, Coro 4I 0I, Falcón, Venezuela. Tel: +58 $0268252-5620$. Email: presidencia@funflc.org.ve

${ }^{3}$ Escola de Química Universidade / Federal do Rio de Janeiro (UFRJ).Av.Athos da Silveira Ramos, I49. Centro de Tecnologia. Rio de Janeiro, RJ, Brasil. Zipcode: 21941-909.Tel: + 55 21 2562-7560. Email: nei@eq.ufri.br

${ }^{4}$ Universidade Federal Rio de Janeiro (UFRJ). Instituto Nacional de Propriedade Industrial (INPI). Praça Mauá, no 7, $10^{\circ}$ andar, sala I0I I. Centro, Rio de Janeiro, RJ, Brasil.Zipcode: 2008I-240.Tel: +55 21 2139-32II.E-mail: aantunes@inpi.gov.br
} 


\section{Introduction}

One of the most striking features of the contemporary world is its constant changing profile, subjected to continuous changes and transformations involving a complexity of dimensions unimaginable until a few years ago. At all times, new scenarios and multiple perspectives on events are unfolding.

Technological advance has been the dominant driving force in modern society leading to a widespread diffusion of products from the rational activity as well as of scientific, technological and administrative sources, which in turn requires new types of management (Antunes et al., 2008). This technological progress has proclaimed a new paradigm based on the development of a set of intensive knowledge on scientific technologies. These technologies represent a range of applications of scientific discoveries, whose core is to develop an increasing competence to manage information and knowledge, as well as their direct applications in the production process. In this contemporary setting, the intangibles such as knowledge (know how), intellectual capital and patents become increasing value strategic variables to occupy the center of contemporary forms of capital accumulation.

The great challenge of the $X X I$ century is to improve and adopt management models that can encourage synergy between science and technology activities along with economic and social development, as well as to promote such activities in their network (Canongia et al., 2004). In this context, Biotechnology is considered one of the most important technological tools nowadays. It is considered a key "future bearing technology" and its applications have contributed to the structuring of new economic and social systems (Santana, 2008 Apud MCT, 2003).

Biotechnology represents a set of technologies "that use biological systems, living organisms or their derivatives to produce or modify products and processes for a specific use" (Convention on Biological Diversity, 1992). It has helped to generate new high-impact services in various industrial segments, with impressive developments in areas of health enabling us to witness a real revolution in the treatment of diseases as well as the use of new drugs for humans. It's also possible to verify its impact in agriculture with the reproduction of plant species and development of functional foods; in the chemical and petrochemical industry with the recovery and treatments of wastes and wastewaters; the sustainable use of biodiversity and in the textile industry with the development of new materials and biodegradable dyes, among other areas.

When assessing the potential application of Modern Biotechnology for the next 20 years, some authors asseverate that areas such as the proteomics (spatial identification of protein structures), genomics, pharmacogenomics, biomaterials, bioengineering, genetic engineering, genetically modified foods and synthetic biology have a great impact in the future (Krattiger, 2002).

Given these promising prospects, the monitoring and searching of scientific advances and trends in this area of knowledge have become essential for searching opportunities in Research and Development (R \& D) and also for potential innovations and business opportunities, both in developed countries as well as in countries of emerging economies such as Venezuela. Countries with rich biodiversity, such as Venezuela, Brazil, Colombia and Peru, among others, have tried to develop national capacities in science and technology (through improving its infrastructure represented by scientific laboratories, bigger participation in networks experts, training of human resources, the increase in national or international publications) that allow a better optimization and application of scientific resources and economics and that can generate technological products based on nationally developed Biotechnology (Torres and Elder, 2009).

In this conjuncture, in order to support the stakeholders in their decision making process on investments, this paper presents science trends for Biotechnology in Venezuela, mapped out through a set of variables such as the identification of the actors involved as well as the institutional partnerships, networking and the major journals, using for this analysis all Venezuelan scientific publications of international dissemination for the period of 1995 to 2010 . 


\section{Biotechnology, The Global Market and Venezuelan Government Programs}

For centuries, humans use Biotechnology in their daily lives. The first actions were reported in the literature as beginning around 2000 BC, when humans learned the art of crossing species of plants and animals as well as the development of fermentation techniques for bread and alcohol production. Since then, the evolution of knowledge has been continuous and Science has focused its efforts to identify and use microorganisms with useful applications for industrial purposes as in the production of vaccines and antibiotics, for example.

However, from 1970 to the "Era of Modern Biotechnology" technological advance has revolutionized the industry as a whole. The discoveries made by Stanley Cohen and Herbert Bayer on reprogramming microorganisms allowed scientists to obtain certain desirable characteristics such as transgenic animals and plants, which became of great interest to various industries like chemical, pharmaceutical, agricultural, food, wastewater treatment, among others. In summary, we can consider that the rupture between the traditional and the modern Biotechnology is focused on the manipulation of genetic material and the creation of new organisms (Gassen, 2000 Apud Santana, 2006).

As technological progress advances based on Life Sciences, the commercial possibilities of obtaining products with higher added value or lower cost of production is growing, attracting an increasing number of companies of various sectors. It is considered that the most prospected areas of global Biotechnology are the ones related to agriculture/ food and health/pharmaceutical. From an economic perspective, Biotechnology is a major focus of activities on research, development and innovation in all industrialized countries (Baker, 2005) becoming increasingly prioritized in developing countries because of their great biodiversity.

The Biotechnology industry has grown rapidly in recent years, more than doubled its worldwide revenue in the last decade, going from US\$ 8 billion in 1993 to US\$ 20 billion in 1999 (Macarenhas, 200I Apud Ernst \& Young, 2000). Figures in this market are not very consistent. According to the Biotechnology Industry Organization (2007), the worldwide market for Biotechnology resources move expressive values of about $\$ 410$ billion per year (2005). According to Ernst \& Young LLP (2010) the United States alone moved Biotechnology industry resources of U.S. \$ 3.7 billion in 2009.
The government policies to support the development and financing on Biotechnology in Venezuela have started since 1980 with the promotion of several programs dedicated to the area, coordinated by the National Council of Science and Technology - CONICIT. There is a governmental structure in the country directed for development of the area. This structure is composed by many ministries such as the Ministry of Science, Technology and Innovation (MST\&I), the Ministry of Environment, Agriculture, Food Industry and Trade, the Ministry of Production and Trade and the Ministry of Health and Social Development. In addition, the Government also acts through its agencies, academia and the private sector.

The financing of Biotechnology research is carried out by federal, private and international agencies. The Organic Law of Science, Technology and Innovation (Decree No. I290 of 26/9/200I) defines some responsible organizations on the national level and the National Foundation for Science, Technology and Innovation - FONACIT represents a leading national organization.

In the late 90th and mid-2000s FONACIT financed a significant number of projects in the area of Biotechnology through an agreement between the Inter-American Development Bank and FONACIT (BID-FONACIT), which allowed direct significant financial resources for researching in this area in the country. There were two major projects: BID-FONACIT I and BID-FONACIT II (2005). These two programs financed some projects led by research institutes such as the Instituto Venezolano de Investigaciones Científicas (IVIC), Fundación Instituto de Estudios Avanzado (IDEA), the Instituto Nacional de Investigaciones Agrícolas (INIA), among others.

In its second phase the BID-FONACIT II has financed 36 projects in areas involving Biotechnology research, in order to promote transfer of technology, training of human resources, strengthen networks, and to improve infrastructure for research centers and R \& $D$. Examples of priority areas supported were: plant and animal breeding, food technology, bioinformatics and immunology, diagnosis and prospecting on Biotechnology and detection of genetically modified organisms (Melendez et al., 2007). Another milestone in this history was the "Science Mission" program in 2006 by the MCT, which 
has guided a major investment for collaborative projects in specific areas prioritized by the Ministry, being one of them the Biotechnology.

\section{Methodology and Recovery Documents}

The research was based on the selection of scientific publications collected in database ISI Web of Science. It is a reliable source of bibliographic data and is used internationally as reference for the generation of indicators of S\&T and Innovation. In order to achieve the purpose of mining scientific production on Biotechnology in Venezuela over a 15 years period (1995-2010), 60 distinct terms (Table I) were used, selected by experts in Biotechnology area sought in the bases CvLac Venezuela (Plataforma Lattes) and Plataforma Lates CNPq / Brazil; by researchers interviewed. A selection from references was also used. All these terms were used to start the search in the database Web of Science. It is noteworthy that the choice of experts was held in order to cover the breadth of Biotechnology. To analyze the themes of scientific publications with international dissemination the fields "Title, Summary and Keyword" were used.

The processing of information from articles retrieved was performed using the software VantagePoint $₫$ as a tool for text and data mining to expand and enrich the results. This tool of information management allows you to present correlations of different variables of interest as well as view maps of collaboration between institutions and countries. It also allows you to identify the top publication journals, the top words or terms most frequently used and build a series of specific variable, among other possibilities.

Macro-indicators were generated, using data and text mining resources, providing a holistic overview of the scientific production on Biotechnology in Venezuela, raising the main issues:

- A total number of articles published per year (19952010) and the tendency to publish the most frequently used terms on Biotechnology;

- Key areas of knowledge and the number of articles published on used terms;

- Major journals that institutions often publish their articles using the most frequent terms on Biotechnology; - Number of papers published by institutions and maps of collaboration between institutions and countries in order to identify partnership networks. 


\begin{tabular}{|l|l|l|l|}
\hline Antisense & Biomaterial & Proteins Engineering & G MO \\
\hline Recombinant Antigen & Biopolymer & Genetic Engineering & Protein \\
\hline Biodiversity & Bioprocess & $\begin{array}{l}\text { Metabolic } \\
\text { Engineering }\end{array}$ & $\begin{array}{l}\text { Recombinant } \\
\text { Protein }\end{array}$ \\
\hline Biocatalyst & Bioprospection & $\begin{array}{l}\text { Molecular } \\
\text { Engineering }\end{array}$ & Proteome \\
\hline Biofuel & Bioreactor & Gene Expression & Proteomic \\
\hline Bioeconomy & Bioremediation & Pharmacogenomics & PCR \\
\hline Bioengineering & Biosensor & Phytoremediation & RNA \\
\hline Bioethics & Biosorption & Gene & Microarray DNA \\
\hline Biofiltration & Biosurfactant & Genetic & Microarray RNA \\
\hline Bioindustry & Biosulfurization & Genome & Transcriptome \\
\hline Bioinformatics & Biotechnology & Genomic & Transgenic \\
\hline Biolixiviation & Stem cells & Microbiota & Cellular Therapy \\
\hline ComputationalBiology & Cloning & Biology Modelling & Gene Therapy \\
\hline Biome & T Cells & Nanobiotechnology & Molecular \\
& & & Therapy \\
\hline Biomass & DNA & Peptide & Vaccine \\
\hline
\end{tabular}

Table I Biotechnology Related Terms used to Search in database ISI Web of Science.

\section{Results and Discussion}

\section{Overview of the Global Scientific Development of Biotechnology in Venezuela}

With regard to the scientific literature on Biotechnology for the period between 1995 and 2010, it was retrieved 803 documents containing terms selected by experts in the fields of title, abstract and keywords, taking Venezuela as the home country. By observing the number of articles published throughout this period, there is an increase in publication trends, which indicates an intensive scientific activity over the past fifteen years, mainly in the last five years, presenting exponential growth with increased production greater than $5,900 \%$, as shown in Figure I.
Through a wider analysis it is possible to observe that these publications occur in association with other countries. Latin America is the region of highest partnership concerning scientific publications on Biotechnology with Venezuela (59.1\%), including itself in this group, followed by Europe $(50.7 \%)$ and subsequently with North America (13.5\%). Figure 2, shown below, represents the distribution by region. 


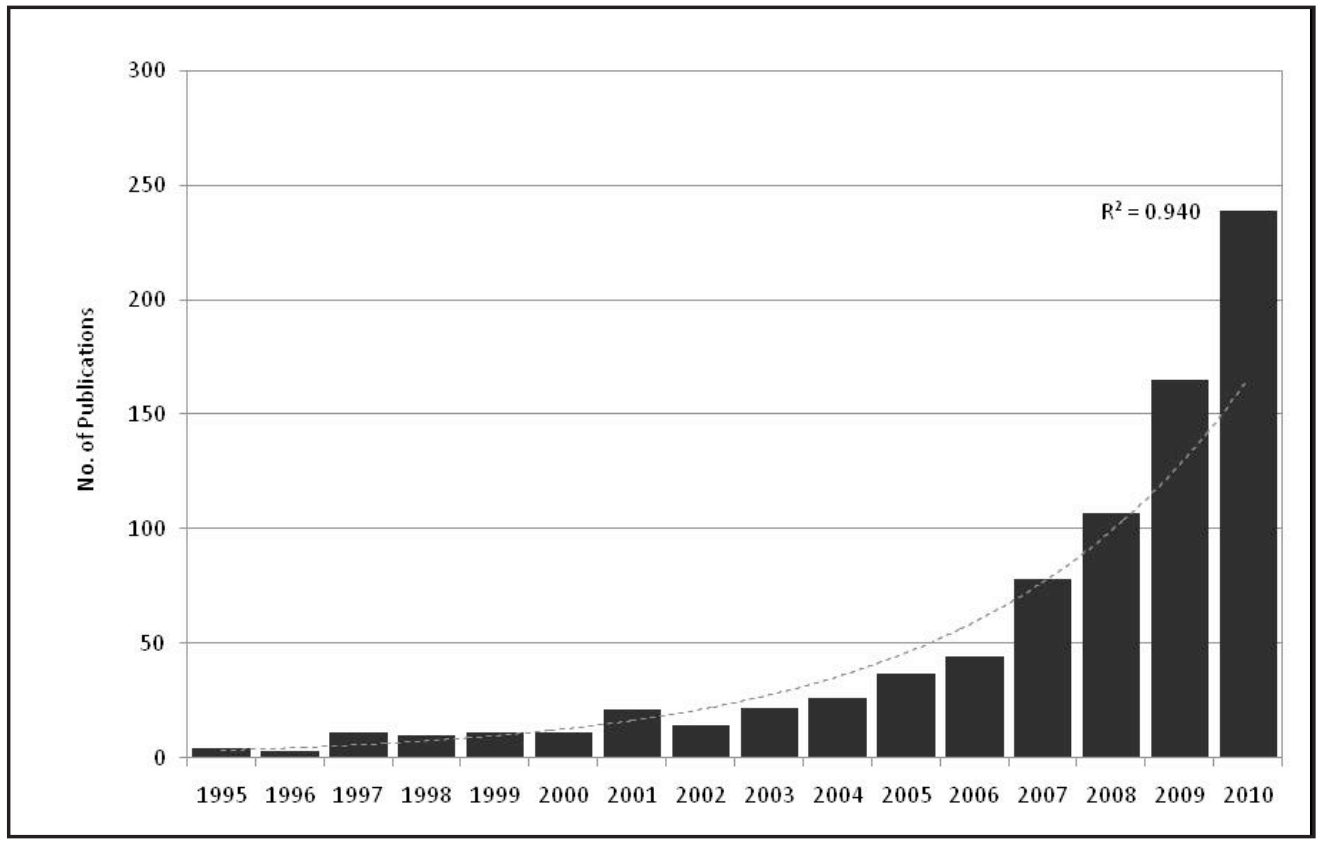

Figure I.Historical Evolution of Biotechnology Scientific Publishing in Venezuela.

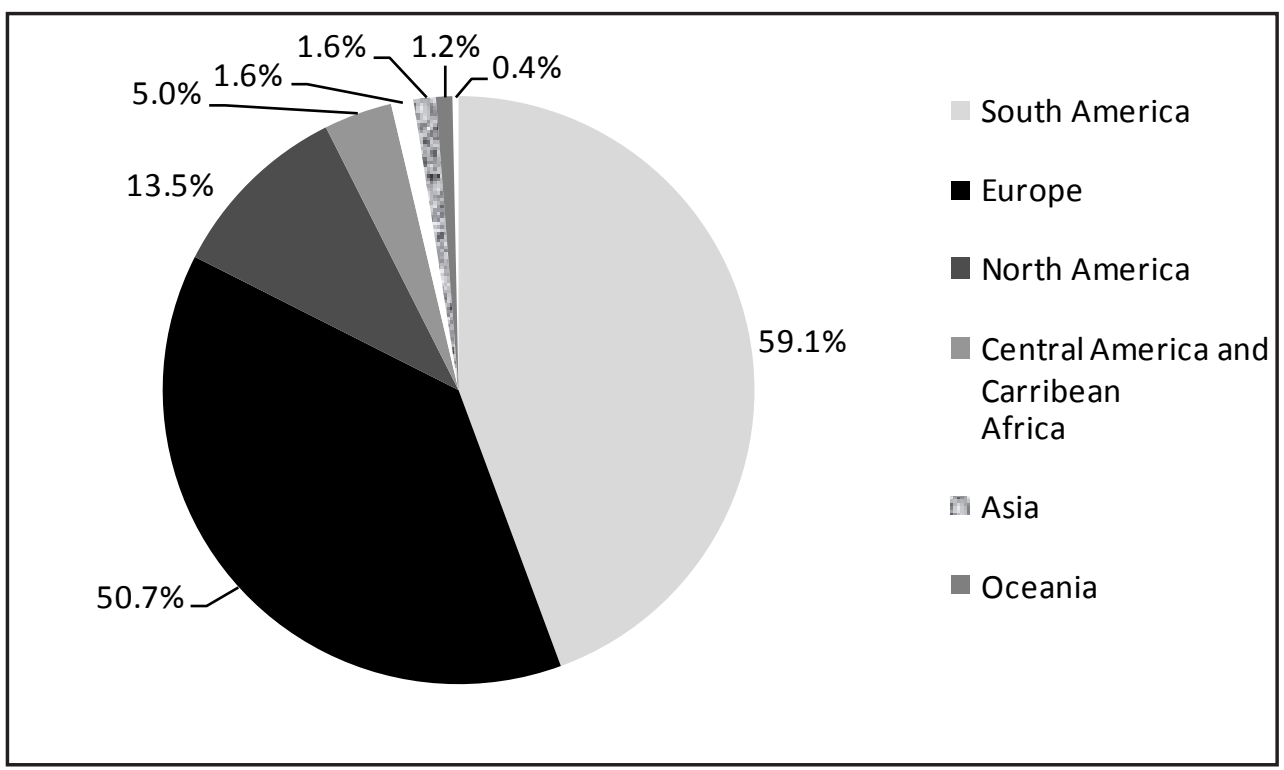

Figure 2. Percentage Distribution of Scientific Venezuelan Publications in Biotechnology with other Regions (1995 - 2010$).$ 
Regarding the most frequently used terms to screen the Biotechnology area in Venezuela, we find a large dispersion in relation to them, which means that there are more than 2,000 different terms (keywords) described by the authors in scientific publications as examples: Leishmania, Chagas disease, Hypertension, among others, which were not used as initial descriptors when searching the database. As for the specific analysis of those terms, it is noted that terms such as PCR and DNA, initially used in searches in the Web of Science database for scientific publications, they are often used since the beginning of the period analyzed, which means that since 1998, these are being associated with Modern Biotechnology Techniques. Other terms such as "Proteomics" (3 articles published in 2007, 2008 and 2009 respectively) and "Stem cell" (I article published in 2008) are less frequent, however, they are related to more advanced future bearing technologies of Modern Biotechnology, being mentioned in Brazil by the National Biotechnology Committee (2008) in the frontier areas of Biotechnology. According to Krattiger (2002) some areas of Biotechnology will have a major impact in the near future in the development of new technologies and its applications, which are: the Genomics, Transcriptomics, Pharmacogenomics, Bioengineering, Biomaterials and Synthetic biology. Some themes related to those terms were detected in this dataset. Table 2 presents terms with more than three citations related to the field of Biotechnology. It also refers to the year where it was first used and the final year of citation in scientific articles, respectively.

Some terms initially used in the search such as PCR, DNA, Biotechnology, Biodiversity, Biomaterial, Vaccine, among others, were listed in Table I, were identified within the set of 2,000 terms found. A few terms in Table I are marked in bold in Table 2 below and represent $1.5 \%$ of all terms found related to the field of Biotechnology.

From the total of scientific publications found, it can be observed that $23 \%$ refer to a potential application and the other remaining publications, because these are related to basic research, and has no exact identification to possible applications. However, the data collected point out that scientific research on Biotechnology in Venezuela is directly related to the study of some relevant social problems of a country mainly related to tropical diseases. 


\begin{tabular}{|c|c|c|c|}
\hline Articles & Top Terms (Keywords) & Articles & Top Terms (Keywords) \\
\hline 48 & PCR (1998/2010) & 6 & Taxonomy (1998/2010) \\
\hline 38 & DNA (1998/2010) & 6 & Malaria (1998/2009) \\
\hline 18 & Biodiversity (2005/2010) & 5 & Biogeography (2007/2009) \\
\hline 17 & $\begin{array}{l}\text { Chronic liver diseases } \\
(2004 / 2010)\end{array}$ & 5 & Dengue (2009/2010) \\
\hline 16 & Genetics (2002/2010) & 5 & ELISA (2001/2009) \\
\hline 15 & Trypanosoma cruzi $(2003 / 2010)$ & 4 & Gene expression (2004/2010) \\
\hline 14 & Leishmania (1999/2010) & 4 & Hypertension (2004/2010) \\
\hline 12 & Immune system (2000/2010) & 4 & $\begin{array}{l}\text { Molecular diagnosis } \\
(2007 / 2010)\end{array}$ \\
\hline 11 & Chagas disease (1998/2010) & 4 & Biomaterial (1997/2009) \\
\hline 10 & E cology $(1999 / 2010)$ & 3 & $\begin{array}{l}\text { Cardiovascular disease } \\
(2008 / 2010)\end{array}$ \\
\hline 10 & Phylogeny $(2002 / 2010)$ & 3 & $\begin{array}{l}\text { Computational screening } \\
(1999 / 2009)\end{array}$ \\
\hline 8 & Genotype (2007/2010) & 3 & Vaccine $(2002 / 2010)$ \\
\hline 7 & $\begin{array}{l}\text { Recombinant protein } \\
(2002 / 2010)\end{array}$ & 3 & Antibacterial (2001/2009) \\
\hline 7 & T cells $(2003 / 2010)$ & 3 & Biofluids (2001/2008) \\
\hline 6 & Bacteria $(2007 / 2010)$ & 3 & Biomarkers (2007/2010) \\
\hline 6 & Biodegradation (2000/2008) & 3 & Biomass $(2009 / 2010)$ \\
\hline 6 & Bovine $(2004 / 2010)$ & 3 & Biotechnology (1997/2005) \\
\hline 6 & Fish (2007/2009) & 3 & Growth factors $(2001 / 2005)$ \\
\hline 6 & Gastric pathologies (2001/2010) & 3 & Proteomic (2007/2009) \\
\hline
\end{tabular}

Table 2. Terms with more than three citations used by authors in the fields Title, Abstract and Keywords in the articles published in Venezuela and the First and Last Years of Citation. 


\section{Profile of the Scientific Sector: Biotechnology}

By its intrinsic multidisciplinary characteristics, Biotechnology permeates many areas of knowledge. Therefore, when analyzing the frequency of publication of scientific areas, there is a predominance of Ecology (13.9\%), followed by Biochemistry and Molecular Biology and Veterinary Science, both representing $9.4 \%$ of total articles published, respectively. However, this study highlights the wide dispersion of scientific publications by all thematic areas. Figure 3 demonstrates this percentage distribution for all the 13 areas with number of articles greater than 30 .

Of the 803 articles published in internationally indexed journals it was possible to notice a trend of publication in these two main thematic areas on Health and Veterinary
Medicine. It is noteworthy that these thematic areas coincide with the main keywords previously identified. Another aspect to note concerns the regional coverage of the top 20 journals, which means that the majority of Venezuelans scientific articles is submitted in Latin American journals (47.6\%), particularly in indexed Venezuelan journals (33\%). This indicator reflects the little dynamics of international cooperation of Venezuelan research groups. Among the indexed journals, the Journal Revista Cientifica Facultad de Ciencias Veterinaria has the highest number of articles (42), followed by other Journals such as Interciencia (4I) and Investigacion Clinica (34).

Table 3 presents the top 21 journals with a number of scientific publications greater than 5 articles.

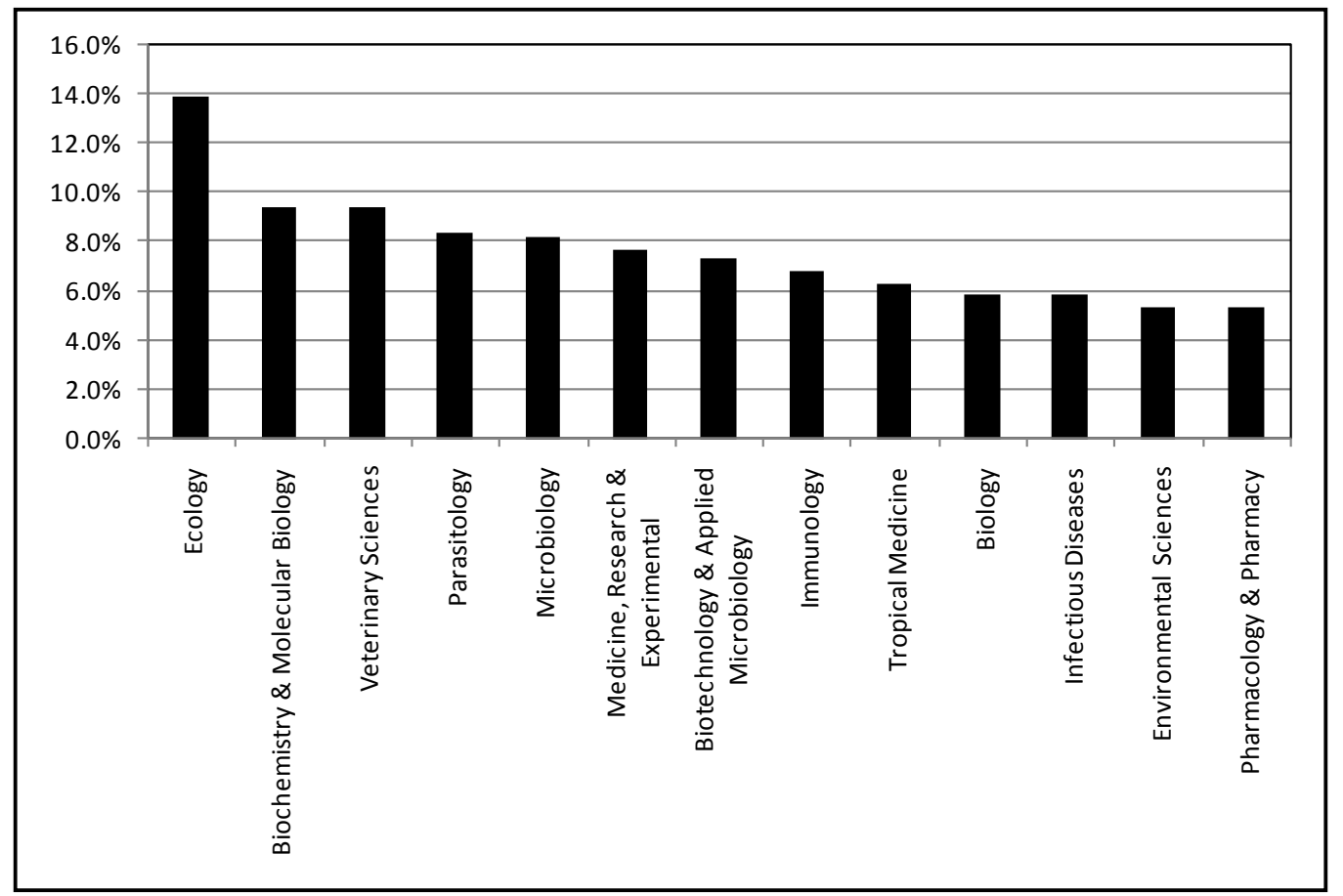

Figure 3. Percentage Distribution of Scientific Publications on Biotechnology by Areas of Knowledge indexed on database. Period I995 to 2010. 


\begin{tabular}{|l|l|l|l|}
\hline J ournals Indexed (Country) & Articles & J ournals Indexed (Country) & Articles \\
\hline $\begin{array}{l}\text { Revista Cientifica Facultad de } \\
\text { Ciencias Veterinarias (Venezuela) }\end{array}$ & 42 & $\begin{array}{l}\text { Boletin de Malariologia y Salud } \\
\text { Ambiental (Venezuela) }\end{array}$ & 7 \\
\hline Interciencia (Venezuela) & 41 & Toxicon (USA) & 7 \\
\hline Investigacion Clinica (Venezuela) & 34 & Conservation Biology (USA) & 6 \\
\hline $\begin{array}{l}\text { Revista de Biologia Tropical } \\
\text { (Costa Rica) }\end{array}$ & 12 & $\begin{array}{l}\text { Molecular and Bioch } \\
\text { Parasitology (USA) }\end{array}$ & 6 \\
\hline $\begin{array}{l}\text { Rev Tec de la Fa de Ingenieria } \\
\text { Universidad del Zulia (Venezuela) }\end{array}$ & 10 & Plos One (USA-UK) & 6 \\
\hline $\begin{array}{l}\text { Acta Microscopica (Venezuela) } \\
\text { Medicine and Hygiene (USA) }\end{array}$ & 8 & Amen J of Therapeutics (USA) & 5 \\
\hline $\begin{array}{l}\text { Rev de la Facultad de Agroia de } \\
\text { la Univ. del Zulia (Venezuela) }\end{array}$ & 8 & Biomedica (Colombia) & 5 \\
\hline $\begin{array}{l}\text { Science (USA) } \\
\text { (G) ournal of Tropical }\end{array}$ & 7 & Revi Chi de Infectologia (Chile) & 5 \\
\hline
\end{tabular}

Table 3./ Main Internationally Indexed Journals with Biotechnology related Articles

Considering the authors' affiliation, it is observed that there are 290 institutions, showing a high dispersion among the authors' institutions. It's important to highlight the significant number of articles produced by institutions such as the Universidad Central de Venezuela (UCV) representing $20 \mathrm{I}$ articles $(25.0 \%)$, followed by the Instituto Venezolano de Investigaciones Científicas (IVIC) with $158(19,7 \%)$ and the University of Zulia (LUZ) with 120 (I4.9\%) articles respectively. Another significant aspect to be observed is the predominance of public governmental institutions such as universities or research centers, revealing a concentration of activities in Biotechnology by public institutions or nonprofits corporations in both academic and investigative levels. It is also worth noting the little number of scientific publications indexed by the Venezuelan companies in the period observed, less than $1 \%$, which indicates a small number of companies working in that area or that they are still consolidating their capacities. Figure 4 shows the institutions that have published more than 10 articles in the observed period. 


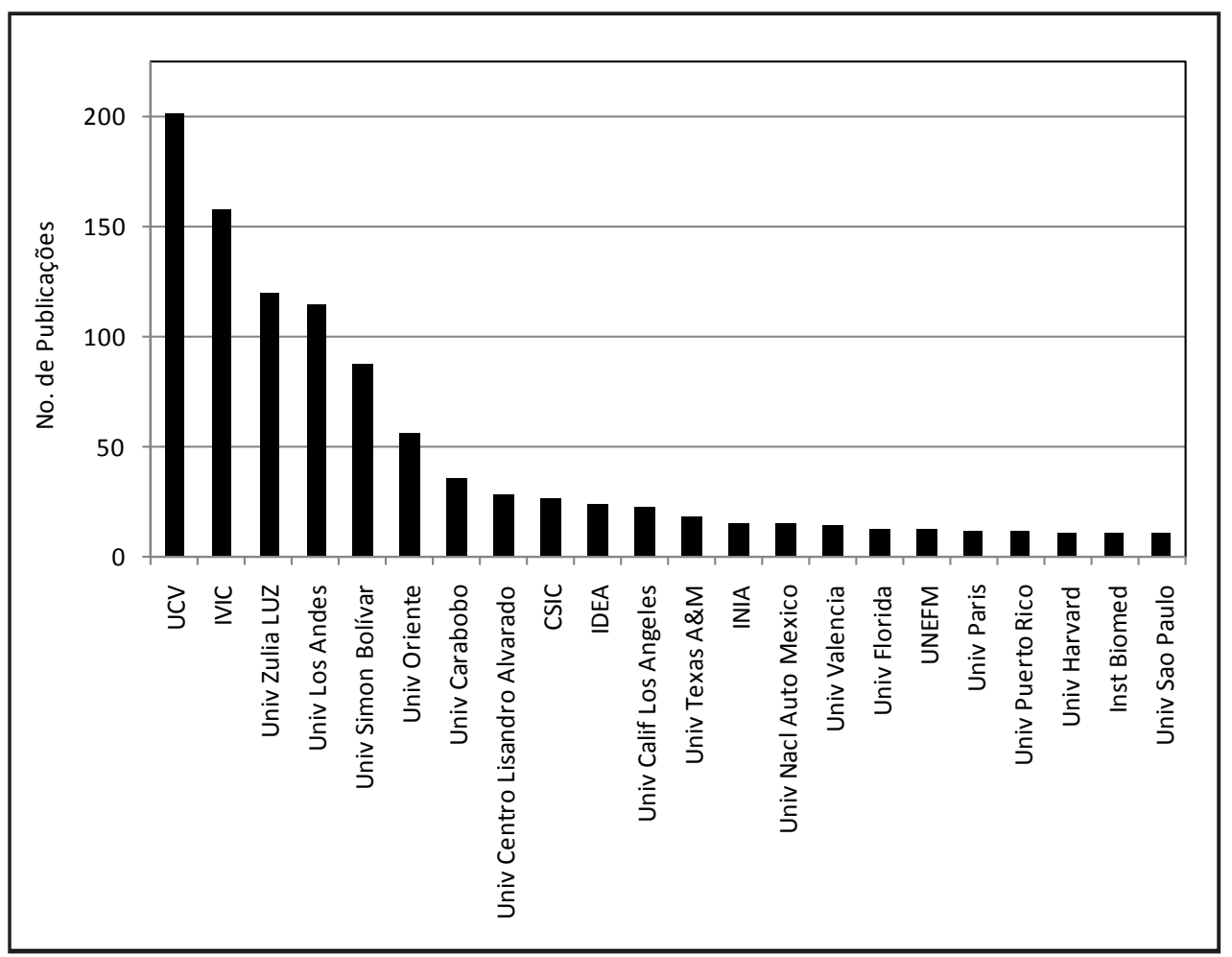

Figure 4. Leading Venezuelan institutions with major publications in Biotechnology for the period 1995-2010.

\section{Maps of Knowledge and Network Collaboration}

Regarding the analysis of relationships between composing agents of the Organizational System of Science, Technology and Innovation within a country, many authors make reference to the central idea of networking and the valuable interactions between system components and its main actors: institutions, organizations and individuals in order to promote the dissemination and use of new scientific knowledge (Freeman, 1987). In accordance with this premises, we sought to observe how these actors relate to each other using the number of publications of scientific cooperation between institutions and between countries, which means an analysis of the links established between the organizations; on a macro level, the international relationships developed by these institutions of $R \& D$. The best representation of these collaborations is the visualization of maps of knowledge where the existence or not of correlations and the degree of its intensity is clear, which provide to decision-makers some strategic subsidies in future planning of national activities of ST \& I.

Regarding the network map of articles' authorship in Venezuela, for the Biotechnology area, it is possible to identify a intensive collaboration between different institutions, es- pecially among Venezuelan institutions showing that $98.8 \%$ of articles are written with internal collaboration, which supports the will to develop endogenous capacity of Venezuelan groups to perform work and publish papers with little support from international cooperation. It is possible to note groups with strong collaboration such as the Universidad Central de Venezuela (UCV), Universidad de Zulia (LUZ) and the Instituto Venezolano de Investigaciones Cientificas (IVIC). These collaborations between Venezuelan institutions demonstrate that relationship are based more heavily on the model of interaction between universities, research centers and non-governmental research centers and of little interaction with companies. It should be emphasized that this scenario has been changing since the implementation of the Organic Law of Science, Technology and Innovation in 200I, where the enterprise sector was encouraged to invest more in internal activities of ST \& I and/or in partnerships with public institutions, aiming to promote alliances between universities and scientific research center with the private sector (LOCTI, 200I). Figure 5 shows the collaboration network among institutions with more than 10 articles published. 


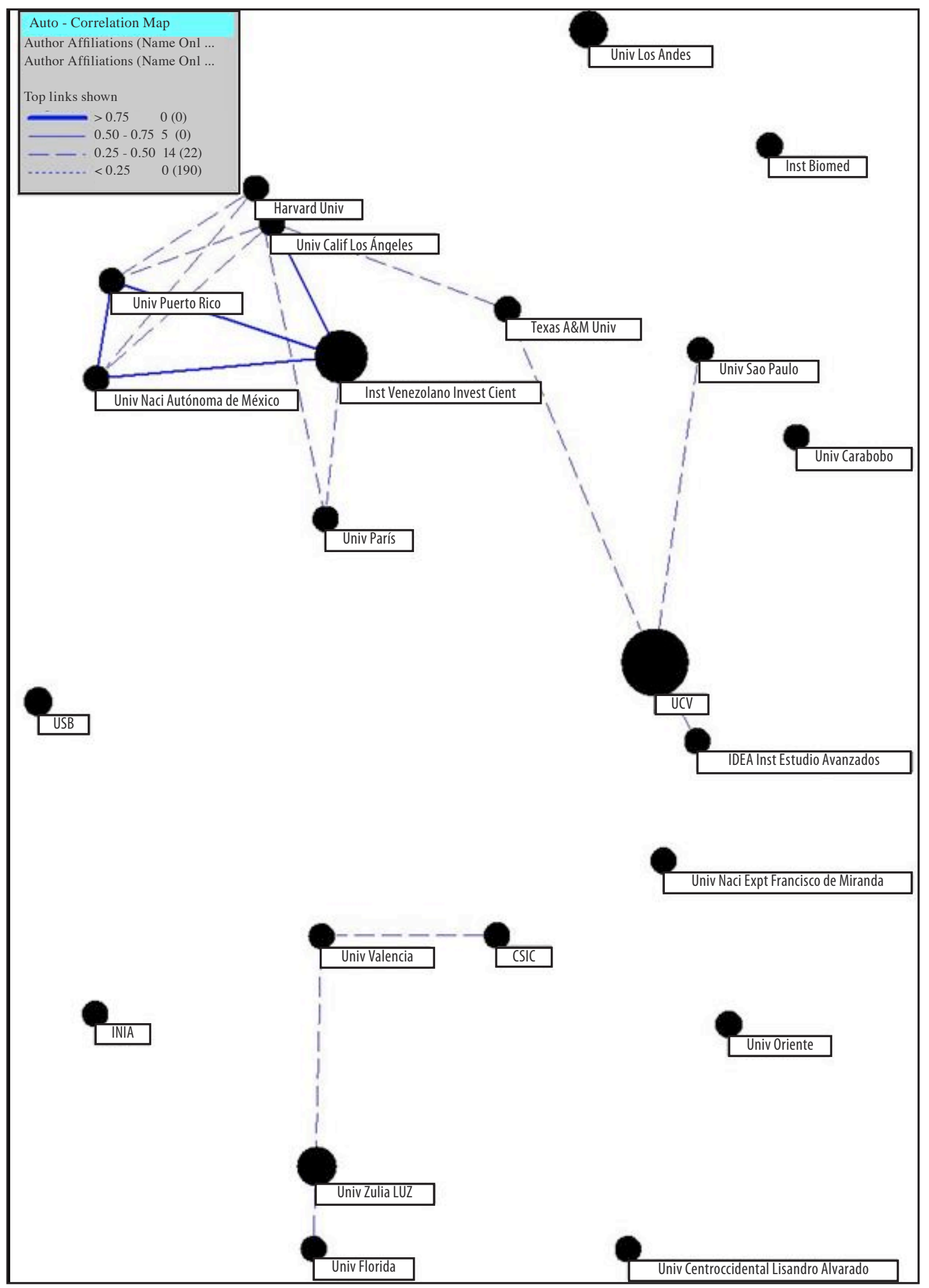

Figure 5. Map of Institutional Relations on Biotechnology for Venezuela./ Source: Graphic presentation software Vantage Point $®$. 
From a macro perspective, there is a large international collaboration, particularly with five countries: The United States (20.3\%), Spain (12.6\%), France (7.5\%), UK (6.3\%) and Brazil (6.2\%). As seen previously, when focusing on Latin America, the main block of scientific cooperation, it's possible to identify that Venezuela has networks of scientific collaboration and research with almost all countries. Brazil is a major co-authored number of articles (6.2\%), followed by Colombia (4.4\%), Argentina $(2.9 \%)$, Chile (2.0\%) and Peru (I.I\%) (Figure 6).

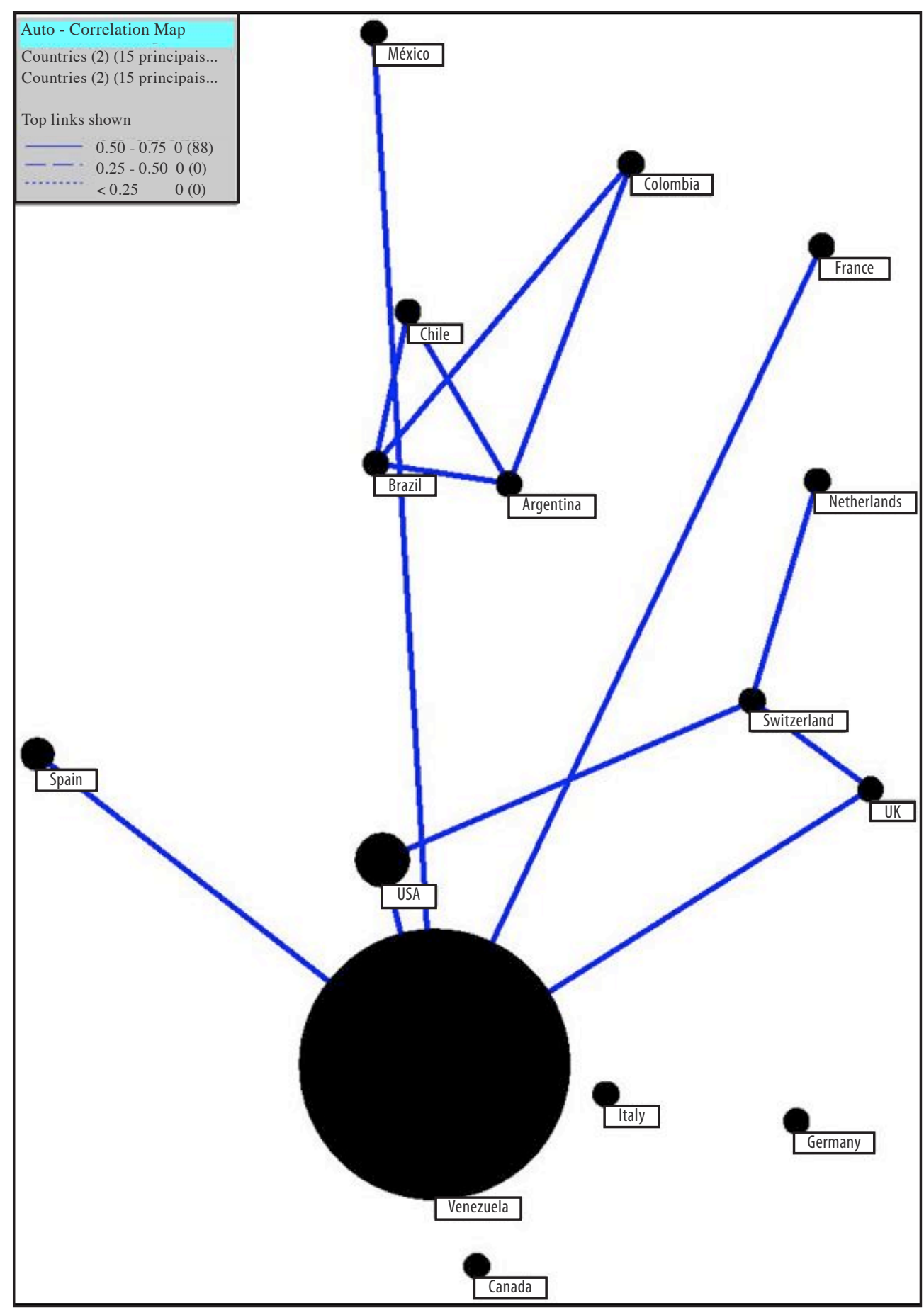

Figure 6. Map of Institutional Relations between Venezuela and the 30 Major Countries./ Source: Graphic presentation software Vantage Point ${ }^{\circledR}$. 


\section{Final Considerations}

Traditionally Biotechnology is a technology that is heavily dependent on the studies of the basic research area. Its success in any country is tightly related to government policies regarding the promotion of science and its technological diffusion. This paper presents the growing momentum of scientific research of Biotechnology in Venezuela, noting a higher growth of $5,900 \%$, in 15 years, over the number of scientific articles published in the area, especially in the last five years.

With respect to searched terms, "PCR" and "DNA" are among the terms most frequently used, being cited by the authors as Keywords in scientific journals since 1998 as well as in main journals such as Rev Cientifica Fac de Ciencias Veterinarias and Interciencia. It is noteworthy that terms related to the frontier area of knowledge have also appeared in this research such as Proteomics and Stem cells, signaling that the scientific research in this area in Venezuela are consistent with trends worldwide.

Another significant aspect is that the Biotechnology scientific research in Venezuela is very relevant for studying the country's social problems, mainly related to tropical diseases, which presents itself as an important starting point for formulating policies on ST\&l, since decision-makers should encourage links between scientific institutions and enterprises. A wide dispersion in relation to the thematic areas of Biotechnology is observed, however, concentrated mainly in areas such as Ecology and Biochemistry and Molecular Biology. Three Institutions are highlighted here: UCV, IVIC and LUZ. It is worth noting that institutions that fulfill scientific research in this area are primarily governmental.

Regarding analysis of relationships between agents that compose the Organizational System of Science, Technology and Innovation in a country, it was found that for Biotechnology, there is a large network of collaboration among national and international institutions, as well as networking among various countries that present a positive factor in the Biotechnological development of a country. Finally, we identified the U.S. as a major coauthor of scientific publications relating the subject, but there are also partnerships with other Latin American countries like Brazil, Colombia and Chile.

\section{References}

ANTUNES, A.M.S.; Canongia, C.; Bahrut, E.; Rodrigues, H.T.; Pio, M.; Gianinne, R. (2008). Prospección tecnológica - gestión del conocimiento y Inteligencia Competitiva: Modelos de Gestión para la Toma de Decisiones y Construcción de Futuro. In: Sinergía entre la Prospectiva Tecnológica y la vigilancia Tecnológica $Y$ Inteligencia Competitiva, Bogotá, Colciencias, pp. 49-83.

BAKER, S; Aston, A. (2005). The Business of Nanotech. Business Week. 14 February, pp. 64.

BIOTECHNOLOGY INDUSTRY ORGANIZATION (2007). Bio Editor's and Reports'Guide to Biotechnology. 2007. http://www.bio.org. (Accessed: January 10, 2010)

BIOTECH GUID APUD ERNEST \& YOUNG LLP BIOWORLD, (2007). Bio Editor's and Reports' Guide to Biotechnology. http://www.bio.org. (Accessed: April 5, 2007).

BURRILL, G.S. (2000). Biotech 90: Into the Next Decade. Biotechnology Industry Organization. International Food Information Council. Ernst \& Young, WC. http://www. bio.org. (Accessed: April 5, 2007)

CANONGIA, C; Pereira, M.N.F.; Mendes, C.U.S., Antunes, A.M.S. (2004). Mapeamento de Inteligência Competitiva (IC) e de Gestão do Conhecimento (GC) no Setor Saúde. R. Eletr. Bibliotecon. Ci. Inf., Florianópolis, n. esp., I० sem. 2004. pp. 78 - 95.

CONVENÇÃO DA BIODIVERSIDADE (Conferência das Nações Unidas sobre o Meio Ambiente e Desenvolvimento-Rio-92). (1992). Revista Estudos Avançados. 6 (15): PP. 193-223. http://www.usp.br/iea/revista.html. (Accessed March, 4, 2004)

COMITÊ NACIONAL DE BIOTECNOLOGIA (2008). Áreas Setoriais: Saúde Humana. Ministério da Indústria e Comércio Exterior (MDIC), Brasília, Pp. I-5.

ERNEST \& YOUNG LLP (2010). Beyond Borders Global Biotechnology Report 2010, WC, pp. I-II6.

FREEMAN, C. (1987). Technology Policy and Economic Perfomance. Lessons from Japan, London and NY, Pinter Publisher, pp 155. 
GASSEN, H. (2000). Biotecnologia para Países em Desenvolvimento. Biotecnologia em Discussão. Cadernos Adenauer, No. 8, pp. 9-18.

KRATTIGER, A.F. (2002). Public-private Partnerships for Efficient Proprietary Biotech Management and Transfer, and Increase Private Sector Investments. A Briefing Paper with Six Proposals. IP Strategy Today, No. 4, Cornell University, USA, PP 42.

LEY ORGANICA DE CIENCIA Y TECNOLOGÍA E INNOVACIÓN (200I). República de Venezuela. Publicada em Gaceta Oficial N. 37.291. September, 26, 2001.

MASCARENHAS, P. (200I). Parque Nacional de Empresas de Biotecnologia, Fundação Biominas, PP I- 250.

MINISTÉRIO DO DESENVOLVIMENTO, INDÚSTRIA E COMÉRCIO EXTERIOR (2003). Diretrizes de política industrial, tecnológica e de comércio exterior. Brasília.

SANTANA, M.F.E.; ANTUNES, A.M.S.; PEREIRA Jr.,N. (2006). O Perfil da Biotecnologia no Brasil. In. Gestão em Biotecnologia, Rio de Janeiro, Editora E-papers, pP 17-42.

TORRES, O.D.; Velho, L. (2009). Capacidades Científicas y Tecnológicas de Colombia para adelantar Prácticas de Bioprospección. Revista CTS, No 12, Vol. 4. pp 55-68. 